dr hab. Matgorzata Kowalska

Uniwersytet Mikołaja Kopernika w Toruniu

Instytut Informacji Naukowej i Bibliologii

koma@umk.pl

\title{
GRZECHY GLÓWNE BIBLIOTEK APLIKUJACYCH O ŚRODKI FINANSOWE Z BUDŻETU MINISTERSTWA NAUKI I SZKOLNICTWA WYŻSZEGO
}

\author{
The Major Sins of the Libraries Applying \\ FOR THE FUNDS FROM THE MINISTRY OF SCIENCE \\ AND Higher Education
}

\begin{abstract}
Abstrakt
W Polsce działalność bibliotek może być finansowana z budżetu państwa, funduszy strukturalnych, dotacji celowych, projektów międzynarodowych oraz ze środków pochodzących od prywatnych fundatorów. Niniejszy artykuł jest próbąomówienia wniosków płynących z analizy formularzyaplikacyjnych składnych przez biblioteki do Ministerstwa Nauki i Szkolnictwa Wyższego w związku z ubieganiem się o środki przeznaczone na działalność upowszechniającą naukę. Autorka - na podstawie swojego doświadczenia jako członka Zespołu interdyscyplinarnego ds. upowszechniania nauki - dokonuje analizy wniosków pod względem merytorycznym. Zebrane na podstawie analiz dane wyraźnie wskazują, że we wnioskach występują zarówno błędy wynikające $\mathrm{z}$ niezrozumienia kryteriów finansowania przyjętych w myśl zapisów Ustawy o zasadach finansowania nauki, jak i będące następstwem ludzkich pomyłek oraz pośpiechu i opieszałości w trakcie przygotowywania formularzy aplikacyjnych.
\end{abstract}

Słowa kluczowe: działalność upowszechniająca naukę, finansowanie działalności bibliotek, finansowanie nauki, wnioski grantowe biblioteczne. 


\begin{abstract}
In Poland, libraries can be financed through the state budget, the structural funds, the targeted subsidies, the international projects and by the private donors. This article attempts to discuss the conclusions of the analysis of the application forms submitted by the libraries to the Ministry of Science and Higher Education on account of applying for the dissemination of the science funds. On the basis of her own experience as a member of the Interdisciplinary team for dissemination of science, the author analyses the library applications. Collected data indicate that the most frequent mistakes found in the library applications result both from some kind of misunderstanding of the funding criteria defined in the Science Funding Act and from the simple human errors that have been made at the stage of the application preparation.
\end{abstract}

Keywords: dissemination of science, financing of library activities, financing of science, library applications.

\title{
Wprowadzenie
}

Jednym $\mathrm{z}$ ważniejszych problemów na etapie podejmowania decyzji o uruchomieniu takiej lub innej działalności jest oszacowanie oraz zapewnienie niezbędnych środków finansowych. Środki te mogą pochodzić zarówno z rezerwy budżetowej danego podmiotu, jak i bogatej oferty źródeł zewnętrznych. W tym drugim przypadku ich pozyskanie nigdy nie jest jednak zadaniem prostym. Najbardziej innowacyjny czy społecznie użyteczny projekt może bowiem zostać zdyskwalifikowany, gdy wnioskodawca błędnie oceni zbieżność celów własnych z celami donatora, niestarannie przygotuje formularz aplikacyjny czy nie uzasadni kosztów realizacji przedsięwzięcia. Dlatego ubieganie się o środki finansowe poprzedzać musi rozeznanie wnioskodawcy w zasadach udzielania wsparcia, przygotowanie analizy finansowej i studium wykonalności projektu oraz skompletowanie niezbędnej dokumentacji. Dotyczy to wszystkich typów wnioskodawców, także tych z sektora kultury - w tym bibliotek.

W Polsce źródłami finansowania działalności bibliotecznej mogą być m.in.: fundusze europejskie (np. programy Kreatywna Europa, Polska Cyfrowa), zagraniczne granty (np. Szwajcarsko-Polski Program Współpracy, Międzynarodowy Fundusz Wyszehradzki), dotacje pochodzące od rozmaitych fundacji i prywatnych darczyńców (np.: Fundacji Aviva, Fundacji Bankowej im. Leopolda Kronenberga, Fundacji Batorego, Fundacji Roberta Boscha, Fundacji Orange, Fundacji TechSoup), a wreszcie wielo- 
letnie programy ministerstw, zwłaszcza Ministerstwa Kultury i Dziedzictwa Narodowego (np.: Kultura cyfrowa, Literatura, Promocja czytelnictwa) oraz Ministerstwa Nauki i Szkolnictwa Wyższego (np. Narodowy Program Rozwoju Humanistyki).

Mimo istnienia szeregu możliwości oraz przygotowywania praktycznych wskazówek dla wnioskodawców ubiegających się o fundusze, wielu bibliotekom nie udaje się jednak otrzymać oczekiwanego wsparcia. Przeszkodą okazują się uchybienia natury formalnej, merytorycznej i finansowej. Dowodów takiego stanu rzeczy dostarcza m.in. - będąca przedmiotem niniejszego artykułu - analiza wniosków aplikacyjnych składanych przez biblioteki naukowe do Ministerstwa Nauki i Szkolnictwa Wyższego (MNiSW). Wypływa ona z doświadczeń autorki jako członka Zespołu ds. upowszechniania nauki (Zespół DUN). W swoim zamierzeniu wyniki przeprowadzonej analizy nie mają piętnować błędów bibliotek aplikujących o fundusze, lecz zwrócić uwagę na te elementy wniosków, które budzą największe wątpliwości przy ocenie i formułowaniu rekomendacji do finansowania.

\section{Zespół DUN}

Zgodnie z Zarządzeniem Ministra Nauki i Szkolnictwa Wyższego $z$ dnia 2 września 2016 r. w sprawie powołania Zespołu interdyscyplinarnego do spraw działalności upowszechniającej naukę , Zespół DUN nie jest organem decyzyjnym, lecz organem doradczym ministra. Do jego zadań należy dokonywanie oceny wniosków o przyznanie środków finansowych na realizację zadań z zakresu działalności upowszechniającej naukę oraz weryfikacja raportów rocznych i raportów końcowych z wykorzystania tych środków. Działalność upowszechniająca naukę definiowana jest przy tym jako realizacja zadań wspierających rozwój polskiej nauki przez upowszechnianie, promocję i popularyzację wyników działalności badawczo-rozwojowej, innowacyjnej i wynalazczej, w tym w skali międzynarodowej, a także zadań związanych z utrzymaniem zasobów bibliotecznych o dużym znaczeniu dla nauki i jej dziedzictwa, nieobejmujących prowadzenia badań naukowych lub prac rozwojowych.

1 Zarządzenie Ministra Nauki i Szkolnictwa Wyższego z dnia 2 września 2016 r. w sprawie powołania Zespołu interdyscyplinarnego do spraw działalności upowszechniającej naukę. Dz.Urz. MNiSW z dnia 15 września 2016, poz. 52. 
Obecny Zespół DUN powołany został we wrześniu 2016 r. na okres dwóch lat. W jego skład wchodzi 22 przedstawicieli różnych dyscyplin naukowych, w tym dwie osoby związane z szeroko pojętymi zagadnieniami działalności bibliotek. Zespół obraduje na posiedzeniach, na których każdy z członków dokonuje sprawozdania powierzonych mu przez przewodniczącego do oceny wniosków oraz rekomendacji ich finansowania. Członkowie Zespołu działają bezstronnie i zobligowani są do zachowania poufności w zakresie procedowanych wniosków. Przewodniczący oraz członkowie Zespołu podlegają wyłączeniu od udziału w rozpatrywaniu i rozstrzyganiu spraw w przypadku, gdy uczestniczyli w opracowywaniu ocenianego wniosku, gdy sprawa dotyczy zatrudniających ich jednostek lub jednostek, w których jest zatrudniona osoba pozostająca z nimi w związku małżeńskim, pokrewieństwie lub powinowactwie do drugiego stopnia albo w takim stosunku prawnym lub faktycznym, że wynik sprawy może mieć wpływ na jej prawa i obowiązki.

Równolegle do ustnego sprawozdania członkowie Zespołu DUN zobowiązani są do przygotowania pisemnych ocen referowanych przez siebie wniosków w systemie teleinformatycznym „Obsługa Strumieni Finansowania” (potocznie „system OSF”)2. W trakcie sporządzania pisemnej opinii konieczne jest odniesienie się do każdego ocenianego kryterium, a następnie sformułowanie ostatecznego wniosku i wnikliwie uzasadnienie rekomendacji finansowania lub jej braku. Po zakończeniu procesu prezentacji wniosków przez danego referenta przewodniczący Zespołu zarządza głosowanie nad każdym omówionym zadaniem. Zespół podejmuje decyzje zwykłą większością głosów. W przypadku równej liczby głosów stanowisko rozstrzygające należy do przewodniczącego. W sytuacji niezgodności opinii przygotowanej przez opiekuna danego wniosku i wyniku głosowania Zespołu, opiekun dokonuje stosownych zmian w systemie OSF, przyjmując jako rozstrzygającą decyzję Zespołu. Ostatnim krokiem jest akceptacja końcowej oceny wniosku w systemie. Na podstawie ocen przygotowanych przez Zespół dla ministra sporządzana jest lista rankingowa wniosków rekomendowanych do finansowania. Zgodnie z zapisami Ustawy z dnia 30 kwietnia 2010 r. o zasadach finansowania nauki (dalej: Ustawa o zasadach finansowania nauki) na zadania upowszechniające naukę minister przeznacza nie mniej niż 10\% środków finansowych na naukę 3 .

2 System OSF. Tryb dostępu: https://osf.opi.org.pl/app/adm/start.do [6 lutego 2018].

3 Ustawa z dnia 30 kwietnia 2010 r. o zasadach finansowania nauki. Dz.U. 2014, poz. 1620 oraz 2015, poz. 249 i 1268. 


\section{Zasady finansowania działalności upowszechniającej naukę ${ }^{4}$}

W myśl zapisów przywołanej już Ustawy o zasadach finansowania nauki oraz Rozporzadzenia Ministra Nauki i Szkolnictwa Wyższego z dnia 8 września 2016 r. określającego szczegółowe kryteria i tryb przyznawania oraz rozliczania środków finansowych na działalność upowszechniająca naukę ${ }^{5}$, a także Rozporządzenia Ministra Nauki i Szkolnictwa Wyższego $z$ dnia 20 września 2016 r. w sprawie pomocy de minimis na finansowanie działalności upowszechniającej naukę do ubiegania się o środki finansowe na działalność upowszechniająca naukę uprawnione są:

1. Jednostki naukowe;

2. Uczelnie;

3. Polska Akademia Umiejętności;

4. Podmioty działające na rzecz nauki;

5. Biblioteki naukowe;

6. Ministrowie kierujący działami administracji rządowej i kierownicy centralnych organów administracji rządowej ${ }^{7}$.

W przypadku działalności bibliotecznej finansowaniem obejmowane są trzy rodzaje czynności:

1. Utrzymanie unikatowych $\mathrm{w}$ skali kraju zasobów bibliotecznych o istotnym znaczeniu dla nauki lub jej dziedzictwa;

2. Opracowywanie naukowych zasobów bibliotecznych;

3. Udostępnianie zasobów bibliotecznych w formie elektronicznej ${ }^{8}$.

Wszystkie wnioski przyjmowane są za pośrednictwem systemu OSF. Przez elektroniczną skrzynkę podawczą do wniosku dołącza się kilka oświadczeń ( $w$ formie dokumentu elektronicznego), w tym o zgodności ze stanem faktycznym i prawnym informacji zawartych we wniosku złożonym w systemie; o wyrażeniu zgody na przesyłanie korespondencji za pomocą

4 Opracowano na podstawie: Praktyczne wskazówki dla Wnioskodawców dotyczace składania wniosków na działalność upowszechniająca naukę. Tryb dostępu: http://www. nauka.gov.pl/ nauka/praktyczne-wskazowki-dla-wnioskodawcow-dotyczace-skladania -wnioskow-na-dzialalnosc-upowszechniajaca-nauke,akcja,print.html [6 lutego 2018].

5 Rozporzadzenie Ministra Nauki i Szkolnictwa Wyższego z dnia 8 września 2016 r. określające szczegółowe kryteria i tryb przyznawania oraz rozliczania środków finansowych na działalność upowszechniająca naukę. Dz.U. 2016, poz. 1514.

6 Rozporzadzenie Ministra Nauki i Szkolnictwa Wyższego z dnia 20 września 2016 r. $w$ sprawie pomocy de minimis na finansowanie działalności upowszechniającej naukę. Dz.U. 2016, poz. 1662.

7 Ustawa $z$ dnia 30 kwietnia 2010 r., dz. cyt.

8 Tamże. 
środków komunikacji elektronicznej; o otrzymywaniu albo nieotrzymywaniu dotacji na działalność statutową; o wykonywaniu w sposób ciągły zadań z zakresu upowszechniania nauki oraz o prowadzeniu prac na rzecz promocji i popularyzacji wyników badań naukowych.

Wnioskodawcom zaleca się, aby określając termin realizacji zadania (termin rozpoczęcia i zakończenia) wzięli pod uwagę nie tylko datę realizacji samego przedsięwzięcia, ale również okres przygotowania do jego realizacji oraz okres niezbędny do rozliczenia, $\mathrm{z}$ uwzględnieniem terminów dokonania zapłaty za wydatki poniesione w związku z realizacją zadania (wydatki poniesione poza terminem realizacji zadania są niekwalifikowalne).

Wnioskodawców obliguje się do szczegółowego uzasadnienia planowanych kosztów realizacji zadania wraz z podaniem ich rodzajów oraz wysokości. Środki finansowe na naukę przyznawane są na okres nie dłuższy niż dwa lata kalendarzowe, począwszy od 1 stycznia roku, na który wniosek jest składany, do 31 grudnia roku następującego po roku, na który składany jest wniosek. Środki finansowe na pokrycie kosztów poniesionych na realizację zadania mogą być przyznane również od dnia 1 stycznia roku, na który wniosek jest składany.

\section{Kryteria oceny wniosków o środki na działalność upowszechniającą naukę}

\section{KRYTERIA OCENY FORMALNEJ}

Pierwszym etapem oceny wniosku jest ocena formalna. Za jej przebieg odpowiada Departament Nauki MNiSW. W praktyce ocena ta ogranicza się do udzielenia odpowiedzi na kilka następujących pytań:

- czy wniosek został złożony $\mathrm{w}$ terminie wynikającym $\mathrm{z}$ rozporządzenia?

- czy wnioskodawca jest podmiotem uprawnionym do złożenia wniosku?

- czy wnioskodawca złożył nie więcej niż jeden wniosek na realizację celów określonych $\mathrm{w}$ art. 25 Ustawy o zasadach finansowania nauki?

- czy w przypadku wniosków partnerskich do wniosku dołączono umowę lub porozumienie o współpracy?

- czy wniosek zawiera stosowne oświadczenia wnioskodawcy?

- czy informacje podstawowe i oświadczenia zostały złożone na elektroniczną skrzynkę podawczą ministra w formie dokumentu elektronicznego opatrzonego kwalifikowanym podpisem 
elektronicznym albo podpisem potwierdzonym profilem zaufanym ePUAP?

- czy wniosek zawiera poprawnie oznaczonego kierownika wnioskodawcy?

- czy informacje podstawowe oraz załączone oświadczenia podpisane zostały przez osoby uprawnione do reprezentowania podmiotu wnioskującego?

- czy termin realizacji zadania nie przekracza terminu określonego w rozporządzeniu (do dwóch lat)?

- czy termin rozpoczęcia oraz zakończenia zadania obejmuje rok, na który składany jest wniosek oraz rok następujący po roku złożenia wniosku, w przypadku zadań dwuletnich?

- czy wniosek jest kompletny: czy wszystkie pola zostały uzupełnione i czy zawiera załączniki?

W przypadku stwierdzenia braków formalnych we wniosku wnioskodawca zobligowany jest do ich uzupełnienia w ciągu siedmiu dni od daty otrzymania wezwania. Nieusunięcie braków w tym terminie skutkuje pozostawieniem wniosku bez rozpoznania. Wnioski niebudzące wątpliwości na etapie oceny formalnej przekazywane są do oceny merytorycznej Zespołu DUN.

\section{Kryteria oceny merytorycznej}

Ocena dokonywana przez Zespół DUN obejmuje cztery rodzaje kryteriów:

1. Kryteria ogólne - weryfikujące związek zadań z przyjętymi przez MNiSW zasadami upowszechniania nauki, celowość planowanych do osiągnięcia efektów, poziom szczegółowości uzasadnienia potrzeby finansowania danego zadania ze środków finansowych na naukę, zasięg i skalę oddziaływania zadania oraz doświadczenie wnioskodawcy w zakresie realizacji podobnych zadań i pozyskiwania środków z innych źródeł finansowania.

2. Kryteria szczegółowe - odnoszące się do przewidzianego do utrzymania, udostępniania lub upowszechniania zasobu bibliotecznego (tj. jego charakterystyki, uzasadnienia wyboru i unikatowości, udziału w długofalowym planie, współpracy z krajowymi i międzynarodowymi sieciami bibliotecznymi) oraz standardów z tym związanych (m.in.: technicznych i osobowych możliwości wnioskodawcy, adekwatności przewidzianych metod i rozwią- 
zań technicznych, zaplanowanych formatów zapisu danych, form udostępniania efektów zadania, wspierania idei otwartości).

3. Kryteria wynikające z Ustawy o zasadach finansowania nauki oceniające wymiar naukowy i utylitarny zaplanowanego zadania, znaczenie jego efektów dla rozwoju nauki oraz odbiorców ze środowiska naukowego (w tym z zagranicy), a także operatywność wnioskodawcy w zakresie pozyskania na realizację zadania środków z innych źródeł finansowania.

4. Kryteria budżetowe - badające zasadność zaplanowanych kosztów (poziom oszacowania pojedynczych składowych kosztów oraz ich adekwatność względem celów).

\section{Najczęstsze błędy pojawiające się we wnioskach bibliotecznych}

Ponieważ ocena natury formalnej leży w gestii Departamentu Nauki MNiSW, a braki stwierdzone w jej trakcie w przypadku wniosków bibliotecznych (najczęściej brak załączników lub podpis niewłaściwej osoby uprawnionej) uzupełniane są w ciągu przewidzianych na ten cel siedmiu dni (w trakcie prac autorki niniejszego artykułu w Zespole DUN nie zdarzyło się jeszcze, by jakikolwiek wniosek biblioteczny odrzucono z powodów formalnych), poniżej odniesiono się wyłącznie do błędów zidentyfikowanych w wyniku oceny merytorycznej oraz finansowej wniosków.

\section{BŁĘDY MERYTORYCZNE}

Analiza 97 zadań bibliotecznych (z ogółem 626, złożonych w ramach 447 wniosków) rozpatrzonych w pierwszej połowie 2017 r. przez Zespół DUN dowodzi, że w opisie zadań pojawiają się usterki i błędy odnoszące się do wszystkich czterech rodzajów kryteriów oceny merytorycznej uwzględnianych przez Zespół DUN. Najbardziej charakterystyczne z nich prezentuje tabela 1 . 
Tabela 1. Najczęstsze usterki merytoryczne pojawiające się we wnioskach bibliotecznych

\begin{tabular}{|c|c|}
\hline Kryteria oceny & Usterki, niejasności, błędy \\
\hline \multicolumn{2}{|c|}{ Kryteria ogólne } \\
\hline $\begin{array}{l}\text { Ocena ogólna elementów działania } \\
\text { związanych z DUN }\end{array}$ & $\begin{array}{l}\text { zbyt lakoniczny opis zamierzeń (np. } \\
\text { digitalizacja } 150 \text { czasopism ze zbio- } \\
\text { rów biblioteki) lub zbyt obszerny opis } \\
\text { zamierzeń obejmujący w zasadzie kilka } \\
\text { odrębnych zadań (np. konserwacja, } \\
\text { digitalizacja, katalogowanie, organizacja } \\
\text { wystaw); } \\
\text { błędy w terminach realizacji zadania } \\
\text { (inne terminy występujące w informa- } \\
\text { cjach podstawowych wniosku, inne - } \\
\text { w opisie merytorycznym); } \\
\text { brak wskazania celu zadania, etapów jego } \\
\text { realizacji, metod działania (np. procesów } \\
\text { konserwacji/digitalizacji), standardów } \\
\text { technicznych, spodziewanych efektów } \\
\text { (np. liczba uzyskanych skanów/ } \\
\text { /rekordów); } \\
\text { brak opisu wcześniejszych projektów } \\
\text { i ich efektów (także tych realizowanych } \\
\text { z DUN), informacji o kontynuacji prac; } \\
\text { brak informacji o doświadczeniu wnio- } \\
\text { skodawcy w realizacji podobnych zadań. }\end{array}$ \\
\hline $\begin{array}{l}\text { Znaczenie zadania dla upowszechnia- } \\
\text { nia informacji o roli nauki w rozwoju } \\
\text { gospodarczym i społecznym kraju }\end{array}$ & $\begin{array}{l}\text { brak informacji o dziedzinach nauki, } \\
\text { w których efekty projektu mogą być } \\
\text { wykorzystane; } \\
\text { brak informacji o potencjalnych odbior- } \\
\text { cach projektu; } \\
\text { - brak informacji o społecznym oddziały- } \\
\text { waniu projektu. }\end{array}$ \\
\hline Zasięg i skala oddziaływania & $\begin{array}{l}\text { niewłaściwe wskazanie zasięgu i skali od- } \\
\text { działywania (np. krajowy dla otwartego } \\
\text { repozytorium; międzynarodowy dla bazy } \\
\text { danych dostępnej wyłącznie na termina- } \\
\text { lach w bibliotece); } \\
\text { - brak dokładnego wskazania, gdzie efekty } \\
\text { zadania będą dostępne. }\end{array}$ \\
\hline
\end{tabular}




\begin{tabular}{|c|c|}
\hline Kryteria oceny & Usterki, niejasności, błędy \\
\hline $\begin{array}{l}\text { Nowoczesność formy i zastosowane } \\
\text { środki techniczne }\end{array}$ & $\begin{array}{l}\text { brak charakterystyki strony WWW } \\
\text { biblioteki, zasobów przez nią dostępnych, } \\
\text { nowoczesnych form kontaktu z bibliote- } \\
\text { karzem, informacji o dostępie do katalo- } \\
\text { gu online. }\end{array}$ \\
\hline \multicolumn{2}{|c|}{ Kryteria szczegółowe } \\
\hline $\begin{array}{l}\text { Charakterystyka zasobu bibliotecz- } \\
\text { nego przewidzianego do utrzymania, } \\
\text { opracowania, udostępniania }\end{array}$ & $\begin{array}{l}\text { - zbyt lakoniczny opis zasobu (brak } \\
\text { przykładowych tytułów prac, zawartości } \\
\text { obiektów, przeznaczenia); } \\
\text { - } \quad \text { brak uzasadnienia wyboru obiektów; } \\
\text { - brak uzasadnienia unikatowości (w skali } \\
\text { kraju, regionu, brak opinii eksperta). }\end{array}$ \\
\hline $\begin{array}{l}\text { Udział zadania w długoterminowym } \\
\text { planie utrzymania, opracowania } \\
\text { i udostępniania zasobów bibliotecz- } \\
\text { nych w postaci elektronicznej }\end{array}$ & $\begin{array}{l}\text { - brak odniesień do wcześniejszych } \\
\text { i planowanych działań o podobnym } \\
\text { charakterze; } \\
\text { - brak deklaracji o zamiarze kontynuowa- } \\
\text { nia prac po zakończeniu finansowania; } \\
\text { - brak informacji o uczestnictwie w krajo- } \\
\text { wych i międzynarodowych programach } \\
\text { dedykowanych współpracy bibliotek; } \\
\text { - brak informacji o rodzajach współpra- } \\
\text { cy w sieciach bibliotecznych (czynna vs } \\
\text { bierna). }\end{array}$ \\
\hline $\begin{array}{l}\text { Adekwatność zastosowanych metod } \\
\text { utrzymania, opracowania i udostęp- } \\
\text { niania zasobów bibliotecznych } \\
\text { w postaci elektronicznej do rodzaju } \\
\text { zasobu, z uwzględnieniem posiada- } \\
\text { nych systemów informatycznych }\end{array}$ & $\begin{array}{l}\text { brak wskazania formatów danych (kopie } \\
\text { matki vs kopie użytkowe), standardów } \\
\text { opisu bibliograficznego (rekord egzem- } \\
\text { plarza vs rekord zasobu); } \\
\text { brak informacji o systemach informa- } \\
\text { tycznych wykorzystywanych do prezenta- } \\
\text { cji zasobu i możliwościach wykorzystania } \\
\text { istniejącej infrastruktury technicznej } \\
\text { biblioteki. }\end{array}$ \\
\hline
\end{tabular}




\begin{tabular}{|c|c|}
\hline Kryteria oceny & Usterki, niejasności, błędy \\
\hline $\begin{array}{l}\text { Formy i zakresy udostępniania zasobu } \\
\text { bibliotecznego w formie elektronicznej }\end{array}$ & $\begin{array}{l}\text { - brak opisu sposobów udostępniania efek- } \\
\text { tów zadania (pełen tekst vs metadane vs } \\
\text { pełen tekst + metadane); } \\
\text { - brak danych nt. oznaczenia obiektów } \\
\text { DOI i innymi identyfikatorami obiektów } \\
\text { cyfrowych; } \\
\text { - brak informacji odnoszących się do } \\
\text { aspektów prawnych. }\end{array}$ \\
\hline \multicolumn{2}{|c|}{ Kryteria z ustawy } \\
\hline $\begin{array}{l}\text { Poziom naukowy prac lub zadań i ich } \\
\text { znaczenie dla rozwoju nauki }\end{array}$ & $\begin{array}{l}\text { brak informacji o dziedzinach nauki, } \\
\text { jakich dotyczy zasób; } \\
\text { brak informacji o potencjalnych odbior- } \\
\text { cach projektu. }\end{array}$ \\
\hline $\begin{array}{l}\text { Praktyczna użyteczność wyników } \\
\text { prac lub zadań oraz ich znaczenie dla } \\
\text { rozwoju innowacyjności i gospodarki }\end{array}$ & $\begin{array}{l}\text { - brak informacji o użyteczności i war- } \\
\text { tości zadania (np.: ochrona dziedzictwa } \\
\text { kulturowego, dokumentacja historii myśli } \\
\text { technicznej, poprawa dostępu do infor- } \\
\text { macji, budowa otwartego społeczeństwa } \\
\text { wiedzy). }\end{array}$ \\
\hline $\begin{array}{l}\text { Znaczenie realizacji prac lub zadań } \\
\text { dla rozwoju międzynarodowej współ- } \\
\text { pracy w zakresie nauki i techniki }\end{array}$ & $\begin{array}{l}\text { - brak informacji o potencjalnych odbior- } \\
\text { cach efektów zadania przez badaczy } \\
\text { w kraju i za granicą (kryterium } \\
\text { językowe). }\end{array}$ \\
\hline $\begin{array}{l}\text { Możliwość współfinansowania } \\
\text { przewidzianych do realizacji prac } \\
\text { lub zadań z innych źródeł niż środki } \\
\text { finansowe na naukę }\end{array}$ & $\begin{array}{l}\text { całkowity brak danych (np. o podjętych } \\
\text { nieskutecznych i skutecznych staraniach } \\
\text { pozyskania środków finansowych na } \\
\text { zadanie z innych źródeł; o braku możli- } \\
\text { wości finansowania z własnych środków). }\end{array}$ \\
\hline
\end{tabular}

Źródło: opracowanie własne.

\section{Błędy w kosztorysach zadań}

Odrębnego omówienia wymagają błędy pojawiające się w budżetach planowych zadań. W pierwszej kolejności należy zwrócić uwagę na fakt, że wielu wnioskodawców wśród wydatków przewidzianych do finansowania ze środków ministerialnych wskazuje koszty niekwalifikowalne z punktu widzenia działalności upowszechniającej naukę. W przypadku organizacji konferencji i imprez kulturalnych są to najczęściej koszty cateringu, uroczystych kolacji, wycieczek dla uczestników i zakupu upominków; zaś 
w przypadku zadań dotyczących utrzymania, opracowania i udostępniania zasobów bibliotecznych - koszty zakupu sprzętu informatycznego (serwerów, komputerów, drukarek, skanerów) i oprogramowania (zakup licencji, dostępu do licencjonowanych baz danych), opracowania graficznego projektów serwisów WWW, administracji i eksploatacji (energia, woda, sprzątanie, ochrona obiektów), które wprawdzie wspomagają działalność upowszechniającą naukę, ale de facto nie mają z nią bezpośredniego związku.

Inną stosunkowo często powtarzającą się usterką jest brak podawania szacunkowych cen jednostkowych efektów poszczególnych czynności (koszt opracowania rekordu egzemplarza, rekordu zasobu, wykonania skanu, mikrofilmowania, konserwacji jednostkowej). Okazuje się, że problem dla wnioskodawców jest także wskazanie w opisie zadań oraz ich kosztorysie liczby osób biorących $\mathrm{w}$ nim udział czy liczby godzin poświęconych na wykonanie konkretnej czynności. W przypadku realizacji zadań z partnerem zewnętrznym, nagminnie brakuje choćby szczątkowej informacji o rozpoznaniu rynku usług i potencjalnych ich kosztach. Ponieważ wyłanianie usługodawcy odbywa się z reguły na drodze przetargu, Zespół DUN a priori przyjmuje założenie, że podanie dokładnych danych na ten temat nie jest możliwe. Brak jakichkolwiek odniesień utrudnia jednak oszacowanie wartości pojedynczych prac, zwłaszcza tym członkom Zespołu DUN, którzy nie orientują się w specyfice działalności bibliotecznej.

$\mathrm{Z}$ pozostałych mankamentów odnoszących się do kwestii finansowych wymienić trzeba jeszcze: zawyżone koszty koordynacji zadań, całkowity brak uzasadnienia pojedynczych wydatków (wymienione tylko ogólne kwoty), błędy w obliczeniach kosztów pośrednich oraz niespójności występujące w tabeli kosztów i opisie merytorycznym zadania (inne kwoty w każdym z tych miejsc).

\section{Podsumowanie}

Konkluzje płynące z przeprowadzonych przez Zespół DUN ocen wniosków bibliotecznych wyraźnie wskazują, że we wnioskach występują zarówno błędy wynikające $\mathrm{z}$ niezrozumienia kryteriów finansowania przyjętych w myśl zapisów Ustawy o zasadach finansowania nauki, jak i będące następstwem ludzkich pomyłek oraz pośpiechu i opieszałości w trakcie przygotowywania formularzy aplikacyjnych.

W pierwszym przypadku odpowiedzialność za taki stan rzeczy ponosi bez wątpienia ustawodawca, który dokładnie nie precyzuje, jakie elementy uzasadnienia powinny znaleźć w opisie pojedynczych kryteriów meryto- 
rycznych i na jakim poziomie szczegółowości powinny one zostać opisane. Częściowo wina leży tu także po stronie Zespołu DUN, który powinien przygotować szczegółową instrukcję wypełnienia wniosku oraz upublicznić katalog inwestycji, zadań i czynności wyłączonych z finansowania.

W przypadku ludzkich błędów trudno nie mieć wrażenia, że pomyłki i nieścisłości są niejednokrotnie efektem opracowywania wniosku przez kilka osób i często „do ostatniej chwili”. Wydaje się, że przeszacowania czy niedoszacowania kosztów realizacji wypływać mogą z kolei z chęci pozyskania jakichkolwiek dodatkowych środków na działalność biblioteczną, zaś przeoczenia czy braki występujące w opisie merytorycznym - ze zbytniej wiary w wiedzę i dociekliwość osób oceniających wnioski („nie podaliśmy informacji o formacie MARC21, bo jest on powszechnie przyjęty za standard opisu”; „nie informowaliśmy o uczestnictwie w WorldCat, bo jest to naturalną konsekwencją współpracy prowadzonej w ramach NUKAT"').

Bez względu na podłoże pojawiających się we wnioskach bibliotecznych usterek, należy w tym miejscu wyraźnie podkreślić, że w odróżnieniu od innych rodzajów wniosków kierowanych do Zespołu DUN (na organizację konferencji, sympozjów i festiwali nauki, promocję wynalazków, tworzenie portali naukowych, produkcję materiałów dydaktycznych w formie elektronicznej), wnioski biblioteczne to materia szczególnie trudna do oceny. $Z$ jednej strony obszerna pod względem ilościowym (niektóre formularze wraz załącznikami przekraczają 140 stron), z drugiej wymagająca orientacji w specyfice działalności bibliotecznej. Aplikując o środki ministerialne, warto mieć świadomość faktu, że wniosek ten może być oceniany także przez tych członków Zespołu DUN, którzy nie mają precyzyjnego rozeznania $\mathrm{w}$ istniejących formach kooperacji bibliotek czy obowiązujących standardach tworzenia, opracowywania i udostępniania zasobów bibliotecznych. $Z$ kolei nawet jeśli jest on oceniany przez specjalistę w tym zakresie, każdy z pozostałych członków Zespołu DUN ma do niego dostęp, co więcej może go zestawiać $\mathrm{z}$ wnioskami innych podmiotów, a wreszcie zadawać pytania uszczegóławiające niejasne zapisy w nim występujące. Warto więc zadbać o to, by pojawiało się ich jak najmniej i by nie budziły one żadnych wątpliwości.

9 Przykłady zaczerpnięte z odwołań wniosków rozpatrzonych negatywnie. Ze względu na klauzulę poufności, dane wnioskodawców nie mogą być ujawnione. 


\section{Bibliografia}

1. Praktyczne wskazówki dla Wnioskodawców dotyczące składania wniosków na działalność upowszechniająca naukę. Tryb dostępu: http://www.nauka. gov.pl/nauka/praktyczne-wskazowki-dla-wnioskodawcow-dotyczace-skladania-wnioskow-na-dzialalnosc-upowszechniajaca-nauke,akcja,print.html [6 lutego 2018].

2. Rozporzadzenie Ministra Nauki i Szkolnictwa Wyższego z dnia 20 września 2016 r. w sprawie pomocy de minimis na finansowanie działalności upowszechniajacej naukę. Dz.U. 2016, poz. 1662.

3. Rozporządzenie Ministra Nauki i Szkolnictwa Wyższego z dnia 8 września 2016 r. określające szczegółowe kryteria $i$ tryb przyznawania oraz rozliczania środków finansowych na działalność upowszechniająca naukę. Dz.U. 2016, poz. 1514.

4. System OSF. Tryb dostępu: https://osf.opi.org.pl/app/adm/start.do [6 lutego 2018].

5. Ustawa $z$ dnia 30 kwietnia 2010 r. o zasadach finansowania nauki. Dz.U. 2014, poz. 1620 oraz 2015, poz. 249 i 1268.

6. Zarządzenie Ministra Nauki i Szkolnictwa Wyższego z dnia 2 września 2016 r. w sprawie powołania Zespołu interdyscyplinarnego do spraw działalności upowszechniającej naukę. Dz. Urz. MNiSW z dnia 15 września 2016, poz. 52. 